\title{
Assessment of Temporal Changes in Water Quality on Selected Parameters in Cole Mere
}

\author{
Surajo Aminu Usman, Aminu Ahmed Aliko, and Abba Sabo
}

\begin{abstract}
Temporal variability in some water quality parameters were investigated through field test and laboratory analysis in Cole Mere over the summer months (June, July and August) of 2013. A total of 10 sites were selected (within the lake) and sampled at approximately month interval. Mean surface water temperature recorded in June, July and August samplings were $14.1^{\circ} \mathrm{C}, 21.9^{\circ} \mathrm{C}$ and $18.2^{\circ} \mathrm{C}$ respectively. The differences in the mean temperature were statistically significant $(p=<0.001)$. Mean Chlorophyll a concentrations were $9.3{\mu \mathrm{gl}^{-1}}^{-1} 15.2 \mu \mathrm{gl}^{-1}$ and $39.8 \mu \mathrm{gl}^{-1}$ for June, July and August respectively and the differences between the months were also statistically significant at $p=0.001$. The observed temporal variability and elevated summer chlorophyll a concentrations are clear indications of eutrophic condition. However, no significant differences were recorded with regards to $\mathrm{pH}$ and dissolved oxygen between the months.
\end{abstract}

Index Terms-Chlorophyll, cole mere, eutrophication, temporal changes.

\section{INTRODUCTION}

As the global population increases, there has been increase in the demand for water and the quality of ground and surface water continues to decline as a result of urban expansion and industrialization. Intensification of agricultural activities and a striking transformation to biogeochemical cycles had deep influence on human contributions of nutrients on the Earth's surface. In Europe and most other part of the world, anthropogenic pressure has been the major problem affecting surface water quality causing eutrophication, acidification, addition of toxic elements, physical changes and dilapidation of littoral habitats [1] and therefore, eutrophication has been constantly ranked as the most important problem affecting surface water quality which is directly associated to public health concerns, economic impacts, ecological and aesthetic damage.

In a natural setting, eutrophication process is very slow and occurs over thousands of years during which lakes slowly age and become more productive, but anthropogenic activities can have a consequential influence on the rate at which these nutrients enters lake, and this can stimulate

Manuscript received April 14, 2014; revised June 6, 2014. This work was supported by University of Wolverhampton for providing transport and laboratory facilities during this work.

S. U. Aminu and A. Sabo are with the Department of Biology, Jigawa State College of Education, P. M. B. 1002 Gumel, Nigeria (e-mail: yasurajringim@gmail.com).

A. A. Aliko is with the Department of Plant Biology, Bayero University P.M.B. 3011, Kano, Nigeria (e-mail: aminu4sail@yahoo.co.in). excessive growth of nuisance algal biomass and macrophytes [2]. Other complications that arise due to eutrophication include depletion of oxygen and inability of the water to support aquatic life (loss of component species), fish kills, damage to biodiversity; loss of water quality for recreational, agricultural, industrial and drinking purposes [3].

Most freshwater bodies including lakes and meres are biologically sensitive to changes in their surrounding environment, which consequently impacts their water quality. Meres are chronically nutrient-rich water bodies that are normally feed predominantly by groundwater supply instead of surface water [4]. There are over 60 Meres and Mosses within the Shropshire-Cheshire plain located in the North-West Midland of England. The lakes are characteristically small, lowland with their depth ranging from 1 to $31 \mathrm{~m}$ [4]. They are situated in depressions in the thick mantle formed as a result of melting of ice-blocks which are deposited in the area dated back to 14-16000 years in the late Devensian period, and many basins in the region are related to glacial deposit formations. All to gather, they form a series of wetland sites that are significant areas of interest [4], [5]. Reference [6] reported that the Meres found in the North West Midlands of England account for a large number of lakes of high conservation significance, though influenced by high nutrient concentrations produced from the agricultural activities and population settlements. Despite the association of meres with eutrophic characteristic for many decades, the great accumulation and consequential variation to aquatic flora have happened over the last 50-100 years.

In recent years, there have been international efforts by the European Union to reduce the amount of nutrient entering water bodies [7]. The main objective of EU Water Frame Work Directive is for rivers to attain good ecological and chemical status by 2015. This has been a major challenge for England and Wales with about 93 per cent of their water bodies facing threat and mostly in an endangered state thereby making it difficult to attain the good status set by the year 2015. Moreover, the two key challenges believed to be associated to this are non-point source pollution and physical changes often connected with agricultural activities and urbanization [1].

As the qualities of surface water continue to deteriorate due to anthropogenic pressure, there have been rules set up by the EU since the adoption of the Directive 76/464/EEC (Discharge of dangerous substances Directive) to protect the surface water against pollution. Measures are set out in the Directive to prevent the direct release of priority contaminants and authorizing the discharge limit for other contaminants. Years later, Water Framework Directive (2000/60/EC) came into force with aim of preventing 
deterioration and enhancing the status of aquatic ecosystems, and the protection regimes in the Directive 76/464/EEC continued into new WFD [8].

However, to achieve common level of ecological quality, the Directive requires individual members to identify their various water bodies, describe their existing ecological status, identify pollutant sources and set up a desired level of quality standard accompanied by an action programme to achieve these standards within a reasonable time frame. To do this, EU Member States have adopted different monitoring system to help determine the ecological and chemical status of their rivers, lakes and other waters bodies. This monitoring is needed by the EU Member States in order to draw a successful management strategy to achieve the objectives set by Water Framework Directive (2000/60/EC) [8].

Eutrophication control on another hand usually includes monitoring of nutrients, major ions and chlorophyll a [9]. The necessity of limiting phosphorus and nitrogen loading to lakes with the aim at controlling eutrophication has been extensively recognized [10]. Emphasis has been focused mainly on controlling phosphorus input to freshwater lakes as a means of controlling eutrophication. In line with achieving the afore-mentioned policies, there is also need to adequately study the temporal variability in the water quality parameters. Therefore, the aim of this paper is achieved through the following objectives: identifying the strategic sampling sites within the lake and its associated inlets and outlet, in-situ and ex-situ monitoring of water quality variables (such as dissolved Oxygen, Temperature and $\mathrm{pH}$ ) and analysing the chlorophyll a concentrations using extraction and spectrophotometry method.

\section{MAterials AND METHODS}

\section{A. Sampling Site}

The research was conducted at Cole Mere lake. Cole Mere is a Country Park positioned $4 \mathrm{~km}$ to the south east of Ellesmere, $1 \mathrm{~km}$ to the east of the A528 and $1 \mathrm{~km}$ south of the A495 with a total area of 54 ha (including the lake). The site is situated within the River Severn basin, which is a typically temperate maritime region, characterised by cooler winters as well as warmer summers, with average annual rainfall of $713 \mathrm{~mm}$ [5]for the region. The lake itself is approximately 27 ha with maximum and mean depth of $11.5 \mathrm{~m}$ and $3.3 \mathrm{~m} \mathrm{[4]} \mathrm{respectively.} \mathrm{The} \mathrm{mere} \mathrm{appears} \mathrm{to} \mathrm{have}$ no stable surface inflows apart from small streams and the Shropshire Union Canal. Notably, the primary source of water that Colemere receives is from ground water origin which constitutes about $61 \%$ to $82 \%$ [5] of the entire water. There is also an artificial outlet to the east of the mere, which drains water out of the meres, but also serves as an artificial inlet during the periods of high water levels. The edges of the mere are surrounded by vegetation (mostly woodlands) and as whole, the mere support important stands of fringe and aquatic plants, as well as notable stands of the rare Least Water-Lily visibly to north side and provides an appropriate habitat for aquatic invertebrate communities. Previous surveys indicate that the lake is eutrophic and high in phosphorus concentration naturally which is believed to be released from internal loading by sediments, however, the nutrient loading could also be through the catchment and by geese as well as other ducks visible within the mere [4], $[5]$.

A total of 10 sampling stations across the whole lake were selected strategically, five from lake shores, three from the lake inlets, one from the canal and the remaining one from the lake outlet.

\section{B. Samples Collection}

Water sampling was undertaken at 10 selected sampling sites distributed across the lake at approximately month interval in June, July and August in 2013; the sampling stations included both open lake shore and its associated inlets and outlets. A GPS reading of each sampling station was recorded during the first sampling. In-situ measurements of temperature, oxygen in $\mathrm{mg} / \mathrm{l}$, percentage saturation were recorded using $\mathrm{HACH}$ portable case multimeter at each sampling occasion and readings were taking at $5 \mathrm{~cm}$ depth below water surface. Water samples were also collected at each sampling station from the near surface of the lake in 1 litre plastic bottles for laboratory analyses.

\section{Sample Analyses}

After every sampling occasion, the samples were then transported to the laboratory for laboratory analyses. $\mathrm{pH}$ of freshly collected samples were measured in the laboratory using $\mathrm{HACH}$ portable case multimeter prior to filtration.

For the determination of chlorophyll $a$ concentration, 250 $\mathrm{cm}^{3}$ of the samples were filtered through. What man GF/C filter with the aid of vacuum. The filters were then rolled with the aid of forceps and transferred to a glass boiling test tubes followed by the addition of $14 \mathrm{~cm}^{3}$ of $96 \%$ methanol solution. Extraction of chlorophyll a pigment was accomplished by placing the bottom of the test tube in a boiling water bath, the methanol was brought to a light simmer and allow to continue for 30 seconds. The extract were then transferred to a $14 \mathrm{ml}$ tube and centrifuged at about $3000 \mathrm{rpm}$ for 5 minutes. The centrifuged extract ready for spectrophotometric analysis was transferred into cuvettes, the spectrophotometer were set and the instrument was calibrated or zeroed with a blank of $96 \%$ methanol solution in a cuvette at $665 \mathrm{~nm}$ wavelength. Absorbance of the samples was measured at this wavelength. The instrument was again set to $750 \mathrm{~nm}$ wavelength and calibrated with a blank $96 \%$ methanol solution in a cuvette and the reading of the absorbance of the samples at this wavelength was also taken.

The chlorophyll a concentrations ware therefore obtained using the relation:

$$
\text { Chla } \mu \mathrm{gl} \mathbf{l}^{-1}=\left(a b s_{665^{-}} a b s_{750}\right) \times 834
$$

\section{Statistical Analysis}

Statistical analysis was carried out using "IBM SPSS Statistics, version 20". Prior to the analysis, the data was log transformed to ensure it is normally distributed. Normality was assessed using the test for skew in Excel. The transformed data was exported from Excel to SPSS for Multivariate ANOVA analysis (MANOVA). However, temporal trends were further investigated by setting post hoc (Bonferroni) test to compare the mean differences between the months, the results are demonstrated in the result chapter (see Table I) by the use of homogenous subsets ( $a, b$ and $c$ ). 


\section{RESUlTS AND DisCUSSION}

Temperature is an important physical parameter used in determining water quality and decrease or increase in temperature may affects other water quality variables. For example, it has been documented that dissolved oxygen solubility decreases with increase in temperature. The temporal changes in temperature over the period of study (June, July and August) are recorded. The mean temperature $\left(14.1^{\circ} \mathrm{C}\right)$ was recorded in June which rose sharply to $21.9^{\circ} \mathrm{C}$ during the July sampling and slightly falls to $18.2^{\circ} \mathrm{Cin}$ August (Fig. 1). The temporal trends in temperature were tested statistically and the result (see Table I) showed a very significant difference between the months $(p=<0.001)$. July is characterised with high temperature, June was the lowest and August falls in between.

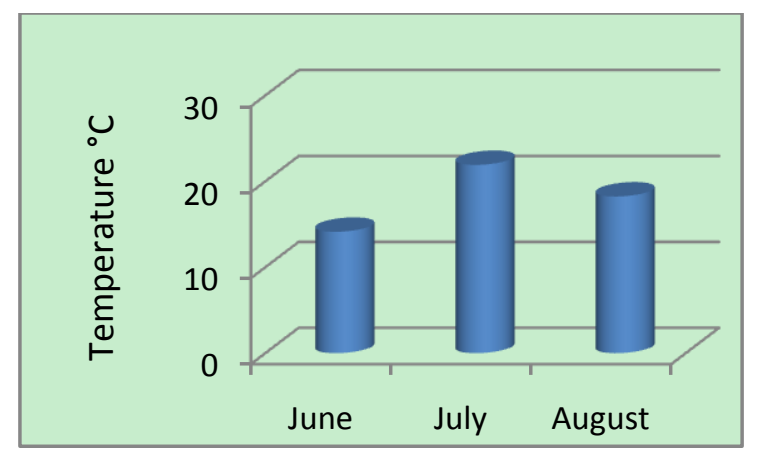

Fig. 1. Temporal variability in temperature $\left({ }^{\circ} \mathrm{C}\right)$ over the study months.

Dissolved oxygen (D.O.) is also another important water quality parameter which can easily be influenced by temperature as explained above. It is an important indicator of the entire aquatic ecosystem health as it controls the organism's metabolism, and generally prescribed that if D.O. level in aquatic system can support fish, it is possible to meet the good ecological quality for other uses. During this study, in all the sites dissolve oxygen varies between $4.6 \mathrm{mg} / \mathrm{l}$ to $12.8 \mathrm{mg} / 1$. in all the lake sampling sites, D.O. was high in July than June and August, although July water temperature is higher than June and August. The rise of D. $\mathrm{O}$ in July could possibly be due to excessive activities photosynthetic of planktons and algae in the surface water [11]. The lower values recorded from the canal and inlet samples in July and August are due to their difference in water chemistry and may be due some contaminants.

$\mathrm{pH}$ as an important physical parameter can be affected by many factors including pollution, photosynthesis and freshwaters input [12]. The mean $\mathrm{pH}$ values recorded in this study are8.27 and 8.37 for July and August respectively and it was low (7.96)in June. $\mathrm{pH}$ concentration from both sources and the mean of each study month fall within the optimum requirement for all river types in England [13] and the proposed 6.5-9.5 [14] based on aesthetic conditions.

Chlorophyll $a$ alongside other variables has been considered as an important water quality index. In this study, temporal changes in chlorophyll $a$ concentration have been recorded through the study period. Summer mean concentrations varied considerably between the months (June $9.37 \mu \mathrm{gl}^{-1}$, July $15.20 \mu \mathrm{gl}^{-1}$ and August $39.81 \mu \mathrm{gl}^{-1}$ ). The mean differences were statistically significant (see Table I) where $p=0.001$. The overall summer mean chlorophyll $a$ concentration $\left(38.1 \mu \mathrm{gl}^{-1}\right)$ calculated during this study is within close range with $\left(42.8 \mu \mathrm{gl}^{-1}\right)$ [4] winter and growth season mean in Cole Mere. In contrast this summer findings were far higher when compared with those of [15], they observed the average water column chlorophyll $a$ in south-eastern Lake Michigan, their average summer values ranged between $1.02 \mu \mathrm{gl}^{-1}$ and $2.22 \mu \mathrm{gl}^{-1}$ during 1995 to 2000 , and $0.70 \mu \mathrm{gl}^{-1}$ and $1.05 \mu \mathrm{gl}^{-1}$ during 2007 to 2011, their result showed that the lake is Oligotrophic while this summer results showed a eutrophic condition. Reference [7] in a survey of three Meres, reported that summer mean chlorophyll in Little Mere was $40 \mu \mathrm{gl}^{-1}$, Mere Mere $42{\mu \mathrm{gl}^{-1}}^{-1994-200)}$ and Rotherne Mere 21.2-66 $\mu \mathrm{gl}^{-1}$, these higher values support the conclusion that the mere are naturally eutrophic.

High Chlorophyll a concentration were recorded at all the sites during this study, this is a clear indication that the mere water quality is deteriorating rapidly as the concentration exceeds oligotrophic level at all sites and the concentration increases temporally reaching hypereutrophic condition in August (Fig. 2). Although summer values are expected to be high due to increasing temperature, and possibly phosphorus released from sediment sand many other factors, the values are still alarming, thus implying the need for further investigations, monitoring and possible restoration measures.

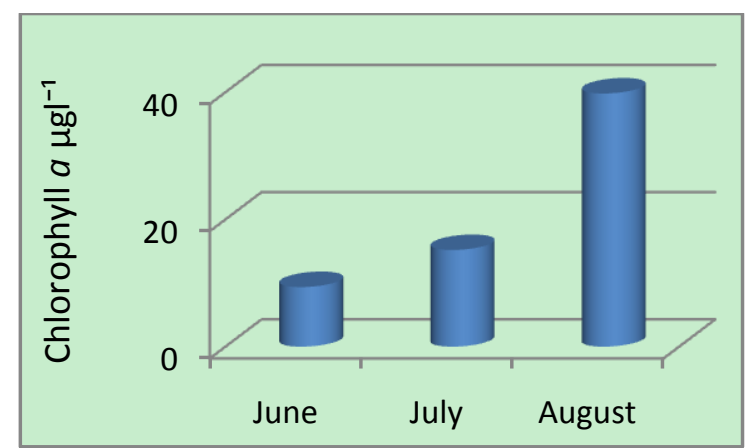

Fig. 2. Temporal variability in chlorophyll a concentration over the study months.

TABLE I: The StATISTICAL DifFERENCE BETWEen THE STUdy MonthS USING ONE-WAY MANOVE (BONFERRONI, POST HOC TEST)

\begin{tabular}{|l|l|l|l|l|l|}
\hline Variables & Months & Mean & SE & F & P \\
\hline \hline Temperature & June & $14.13 \mathrm{a}$ & 0.019 & 25.666 & 0.00 \\
\hline & July & $21.92 \mathrm{~b}$ & & & \\
\hline & August & $18.24 \mathrm{c}$ & & & \\
\hline \hline Oxygen & June & 10.16 & 0.037 & 1.327 & 0.285 \\
\hline & July & 9.16 & & & \\
\hline & August & 8.32 & & & \\
\hline \hline $\mathrm{pH}$ & June & 7.96 & 0.019 & 1.477 & 0.249 \\
\hline & July & 8.37 & & & \\
\hline & August & 8.27 & & & \\
\hline \hline Chlorophyll a & June & $9.37 \mathrm{a}$ & 0.107 & 8.973 & 0.01 \\
\hline & July & $15.20 \mathrm{a}$ & & & \\
\hline & August & $39.81 \mathrm{~b}$ & & & \\
\hline \hline
\end{tabular}

Means with the same letter ( $a, b$ or $c$ ) are not significantly different from each other.

\section{ACKNOWLEDGMENT}

We are greatful to Dr M. Ka'abu for suggesting improvements to the paper. S. U. Aminu thanks Dr. Tobin 
Catherine M,Dr. Farr Katherine M, Dr. McCrea Alison and Black Andrew W. of University of Wolverhampton for their assistance in data collection and laboratory analysis and also for their useful comments during this study.

\section{REFERENCES}

[1] G. Heckrath and G. H. Rubæk, "Diffuse phosphorus loss risk assessment, mitigation options and ecological effects in river basins," presented at The 5th International Phosphorus Workshop (IPW5) in Silkeborg, Denmark, September 2007.

[2] J. E. Cloern, "Our evolving conceptual model of the coastal eutrophication problem," Marine Ecology Progress Series, vol. 210, pp. 223-253, January 2001.

[3] R. W. McDowell and D. P. Hamilton. (2013). Nutrients and eutrophication: introduction. Marine and Freshwater Research. [Online]. 64(5), pp. 3-6. Available: http://www.publish.csiro.au/?act=view_file\&file_id=MF13059.pdf

[4] J. Fisher, T. Barker, C. James, and S. Clarke. (June 2009). Water quality in chronically nutrient-rich lakes: the examples of the Shropshire-Cheshire meres. Fresh water Reviews. [Online]. 2, pp. 7999. Available: http://www.bioone.org/doi/abs/10.1608/FRJ-2.1.5

[5] R. Mileto, "Colemere management plan 2008-2013," Shropshire Council, 2010.

[6] B. Moss, T. Barker, D. Stephen, A. E. Williams, J. David, B. M. Beklioglu, and L. Carvalho. "Consequences of reduced nutrient lading on a lake system in a lowland catchment: Deviations from the Norm," Freshwater Biology, vol. 50, pp. 1687-1705, June 2005.

[7] I. R. Calder, J. Harrison, T. R. Nisbet, and R. J. Smithers, "Woodland actions for biodiversity and their role in water management: Flooding, Water and the Landscape," Journal of Practical Ecology and Conservation, vol. 7, no. 1, pp. 153-163, 2008.

[8] Environment Agency. Impact assessment of the river basin management plan for the humber river basin district. [Online]. pp. 126, December 2009. Available: http://www.environmentagency.gov.uk/static/documents/Research/Hu mber

[9] D. V. Chapman, Water Quality Assessments: A Guide to the Use of Biota, Sediments and Water in Environmental Monitoring, London: E \& FN Spon, 1996, p. 626.

[10] D. J. Conley, H. W. Paerl, R. W. Howarth, D. F. Boesch, S. P. Seitzinger, K. E. Havens, C. Lancelot, and G. E. Likens, "Controlling eutrophication: nitrogen and phosphorus," Science, vol. 323, no. 5917, pp. 1014-1015, February 2009.
[11] J. A. Dar, M. F. Mir, N. A. Bhat, and M. A. Bhat, "Pollution studies of a monomictic lake, Srinagar, Jammu and Kashmir," India Forest Res, vol. 2, no. 110, pp. 1-4, June 2013.

[12] S. P. Hosmani and T. B. Mruthunjaya, "Impact of plankton diversity on the water quality index in a lake at Thirumakudal Narasipura Mysore district," International Journal of Innovative Research in Science, Engineering and Technology, vol. 2, no. 5 pp. 1432-1441, May 2013.

[13] Environmental Standard Conditions Phase 1, WFD UK TAG, April 2008.

[14] World Health Organization. (2008). Guidelines for drinking-water quality [electronic resource]: Incorporating 1st and 2nd addenda. Geneva. $\quad$ OOnline]. $\quad 1.2$ Available: http://www.who.int/water_sanitation_health/dwq/fulltext.pdf

[15] S. A. Pothoven and G. L. Fahnenstiel. (June 2013). Recent change in summer chlorophyll a dynamics of southeastern Lake Michigan. Journal of Great Lakes Research. [Online]. 38. pp. 287-294. Available:

http://www.glerl.noaa.gov/pubs/fulltext/2013/20130006.pdf

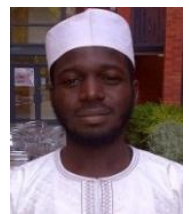

Surajo Aminu Usman is a lecturer at the Department of Biology, Jigawa State College of Education, Gumel, Nigeria. He holds B.Sc. degree in biology at Usmanu Danfodio University, Sokoto, Nigeria and M.Sc. degree in environmental technology at University of Wolvehampton.

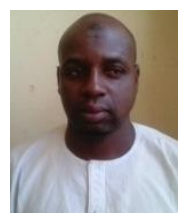

Abba Sabo is a lecturer in the Biology Department, Jigawa State College of Education, Gumel, Nigeria. He holds a B.Sc. degree in microbiolgy from Usmanu Danfodio University, Sokoto. He attended National and International Conferences held in Mauritius, Serea-Leone and Dubai with published papers in reputable journals.

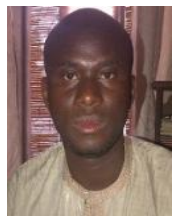

Aminu Ahmed Aliko is a lecturer at the Department of Plant Biology, BayeroUniversit, Kano, Nigeria. He obtained his B.Sc and M.Sc. degrees in botany (plant physiology) from the same Institution he is teaching. 


\section{Energy-Saving Technology}


